\title{
Influences of somatic donor cell sex on in vitro and in vivo embryo development following somatic cell nuclear transfer in pigs
}

\author{
Jae-Gyu Yoo 1,a , Byeong-Woo Kim 2,a , Mi-Rung Park', Deug-Nam Kwon ${ }^{3}$, Yun-Jung Choi ${ }^{3}$, Teak-Soon Shin², \\ Byung-Wook Cho' ${ }^{2}$ Jakyeom Seo ${ }^{2}$, Jin-Hoi Kim ${ }^{3}$, and Seong-Keun $\mathrm{Cho}^{2, *}$
}

* Corresponding Author: Seong-Keun Cho Tel: +82-55-350-5511, Fax: +82-55-350-5519,

E-mail: skcho@pusan.ac.kr

'Animal Diseases and Biosecurity Team, National Institute of Animal Science, Rural Development Administration, Wanju 55365, Korea

2 Department of Animal Science, Life and Industry Convergence Research Institute, Pusan National University, Miryang 627-706, Korea

3 Department of Animal Biotechnology, KonKuk

University, Seoul 143-701, Korea

a These authors contributed equally to this work. Submitted Aug 4, 2016; Revised Sept 12, 2016; Accepted Oct 18, 2016
Objective: The present study investigates pre- and post-implantation developmental competence of nuclear-transferred porcine embryos derived from male and female fetal fibroblasts. Methods: Male and female fetal fibroblasts were transferred to in vitro-matured enucleated oocytes and in vitro and in vivo developmental competence of reconstructed embryos was investigated. And, a total of 6,789 female fibroblast nuclear-transferred embryos were surgically transferred into 41 surrogate gilts and 4,746 male fibroblast nuclear-transferred embryos were surgically transferred into 25 surrogate gilts.

Results: The competence to develop into blastocysts was not significantly different between the sexes. The mean cell number of female and male cloned blastocysts obtained by in vivo culture (143.8 \pm 10.5 to $159.2 \pm 14.8$ ) was higher than that of in vitro culture of somatic cell nuclear transfer (SCNT) groups (31.4 \pm 8.3 to $33.4 \pm 11.1)$. After embryo transfer, 5 pregnant gilts from each treatment delivered 15 female and 22 male piglets. The average birth weight of the cloned piglets, gestation length, and the postnatal survival rates were not significantly different $(\mathrm{p}<0.05)$ between sexes.

Conclusion: The present study found that the sex difference of the nuclear donor does not affect the developmental rate of porcine SCNT embryos. Furthermore, postnatal survivability of the cloned piglets was not affected by the sex of the donor cell.

Keywords: Somatic Cell Nuclear Transfer; Pigs; Donor Cells; Sex

\section{INTRODUCTION}

The technique of somatic cell cloning in mammalians has been developed in the last few decades after the production of the first cloned sheep from a mammary gland cell [1]. Ever since the first somatic cell cloned pigs were produced by three different research groups [2-4], the technology of somatic cell cloning in animals has been applied to many fields, such as genetic improvement of farm animals, rescue of endangered species, and production of transgenic animals for bioscience research and agricultural purposes [5-7]. To date, porcine somatic cell cloning has been very difficult, with only $1 \%$ to $7 \%$ of the reconstructed embryos developing to full term [8]. The difficulty in porcine cloning has been attributed to multiple factors, including quality of recipient oocytes (in vivo vs in vitro matured), donor cell type, inadequate culture and manipulation media, oocyte activation method, requirement of a minimum number of fetuses, and adequate recipient conditions to maintain a pregnancy in the pig [9]. Several factors related to production of the cloned animals might affect the success rate of pig cloning, such as recipient breed [10], ovulation status of surrogate, in vitro culture time of the transferred cloned embryos [11-14], transferred cloned embryo number per surrogate [6,15], embryo transfer position [6], and embryo handling and transfer methods [16]. 
Previous studies have applied different approaches for improving pig cloning efficiency and proposed that the selection of a suitable donor cell type could increase the success rate of cloned piglets $[15,17]$. In cows, comparison of the efficiencies of various cell types from adult, newborn, and fetal male and female donor cells showed no significant difference in the percentages of blastocysts produced from each cell type [18]. Similar results have been attained using various cell types derived from different strains, sexes, and ages in mice [19]. Based on these studies, the use of donor cells from different origins was discovered to be one of the key factors affecting cloning efficiency and survival rates of cloned piglets. Therefore, effort must be undertaken to minimize inefficiencies at each step of the somatic cell cloning procedure. In previous research, the developmental competences of male and female somatic cell derived nuclear transferred embryos have not been adequately studied [20]. Therefore, the present study was conducted to investigate the developmental competence of somatic cell cloned porcine embryos derived from either a male or female fetal fibroblast cell as the donor cell.

\section{MATERIAL AND METHODS}

\section{Chemicals and media}

Unless otherwise stated, all chemicals, media and reagents used in the present study were purchased from Sigma-Aldrich Chemical Company (St. Louis, MO, USA). All animal experiments were approved by and performed following the guidelines of the Pusan National University Animal Care and Experimentation Committee.

\section{In vitro maturation of oocytes}

Porcine ovaries were obtained from prepubertal gilts at a local slaughterhouse and transported to the laboratory at $30^{\circ} \mathrm{C}$ to $35^{\circ} \mathrm{C}$. Cumulus-oocyte complexes (COCs) were aspirated from antral follicles (3 to $6 \mathrm{~mm}$ in diameter) with an 18-gauge needle. COCs with evenly granulated cytoplasm and at least three uniform layers of compact cumulus cells were selected for further study and washed three times in HEPES-buffered North Carolina State University (NCSU-23) medium supplemented with $0.1 \%$ polyvinyl alcohol (PVA). The COCs were then cultured in 500 $\mathrm{mL}$ of maturation medium in four-well multidishes. The maturation medium was a modified NCSU-23 solution containing $10 \%(\mathrm{v} / \mathrm{v})$ porcine follicular fluid, $0.6 \mathrm{mM}$ cysteine, $1 \mathrm{mM}$ dibutyryl cyclic adenosine monophosphate (dbcAMP), and 0.1 IU/mL human menopausal gonadotropin (Teikokuzoki, Tokyo, Japan). The maturation process was carried out for $20 \mathrm{~h}$ in the above medium at $38.5^{\circ} \mathrm{C}$ (with $5 \% \mathrm{CO} 2$ and humidified air) and oocytes were subsequently cultured in the maturation medium without dbcAMP and hormones for another 18 to $24 \mathrm{~h}$ as previously described [21].

\section{Isolation and culture of porcine somatic cells}

Fibroblasts were isolated from pig fetuses on days 30 to 40 of gestation and the sex of the fetal fibroblasts were confirmed using polymerase chain reaction (Figure 1). The cells were cultured in Dulbecco's modified Eagle's medium supplemented with $10 \%$ fetal bovine serum under $5 \% \mathrm{CO} 2$, at $38.5^{\circ} \mathrm{C}$ in a humidified atmosphere. After reaching confluence, the cells were passaged. Donor cells were used for nuclear transfer between passages 4 and 10 of the culture, and the cells were used for nuclear transfer within 3 days of reaching confluence.

\section{Somatic cell nuclear transfer}

Somatic cell nuclear transfer (SCNT) was performed as previously described [21]. Briefly, the matured eggs with the first polar body were cultured in medium supplemented with 0.4 $\mathrm{mg} / \mathrm{mL}$ demecolcine and $0.05 \mathrm{~mol} / \mathrm{L}$ sucrose for $1 \mathrm{~h}$. Sucrose was used to enlarge the perivitelline space of the eggs. Treated eggs with a protruding membrane were moved to medium supplemented with $5 \mathrm{mg} / \mathrm{mL}$ cytochalasin B and $0.4 \mathrm{mg} / \mathrm{mL}$ demecolcine and the protrusion was removed using a beveled pipette as the micromanipulator. A single donor cell was injected into the perivitelline space of an enucleated oocyte and electrically fused using two direct current pulses of $150 \mathrm{~V} / \mathrm{mm}$ for $50 \mu \mathrm{s}$ in $0.28 \mathrm{~mol} / \mathrm{L}$ mannitol supplemented with $0.1 \mathrm{mM} \mathrm{MgSO}_{4}$ and $0.01 \%$ PVA. Fused oocytes were then incubated in PZM5 medium containing $3 \mathrm{mg} / \mathrm{mL}$ fatty acid free for seven days with $5 \% \mathrm{CO}_{2}$ at $38.5^{\circ} \mathrm{C}$ in a humidified atmosphere, or for two days followed by transfer into the oviducts of recipient gilts. In the latter case, embryos were either harvested five days after transfer or allowed to develop to term.

\section{Estrus synchronization}

Estrus synchronization for preparation of recipients was carried out as previously described [3,21]. Briefly, an i.m. injection of $0.2 \mathrm{mg}$ cloprostenol, a prostaglandin F2 alpha analogue (Planate; Sumitomo Seiyaku, Osaka, Japan), was administered to pregnant gilts ( 8 mo old, 120 to $130 \mathrm{~kg}$ ) on days 33 to 53 of gestation, followed by a second injection of $0.2 \mathrm{mg}$ cloprostenol $24 \mathrm{~h}$ later. One thousand international units of eCG (PMS 1000; Tani, NZ)

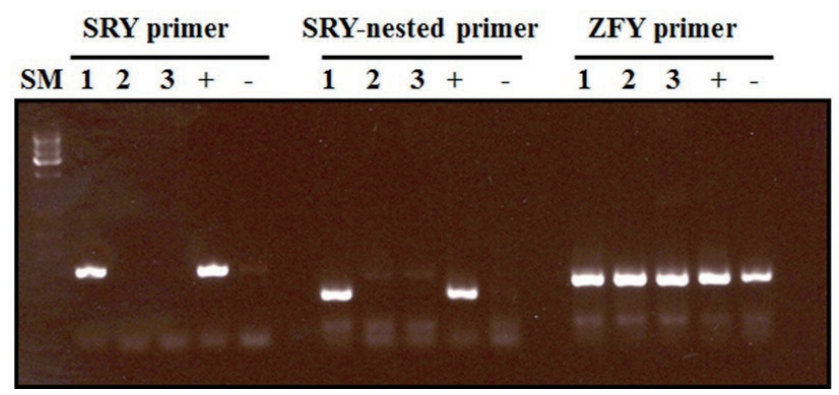

Figure 1. Sexing of porcine fetal fibroblast cells by polymerase chain reaction assay SM, ATGene size marker; 1, fetus 1 (male); 2, fetus 2 (female); and 3, fetus 3 (female); + , positive control (known male gDNA); -, negative control (known female gDNA). 
was administrated i.m. at the same time as the second cloprostenol injection. Ovulation was induced by i.m. injection of 500 IU hCG (Puberogen; Sankyo, Tokyo, Japan) $72 \mathrm{~h}$ after the eCG injection. Ovulation was expected to occur 41 to $42 \mathrm{~h}$ after the hCG injection.

\section{Embryo transfer}

The nuclear-transferred eggs were activated with electric pulses and cultured for one or two days. One or two cells of SCNT embryos were surgically transferred into oviducts of synchronized recipients. The pregnancy status of recipients between days 30 and 35 was determined using ultrasound.

\section{Microsatellite analysis}

Parentage analysis was performed on the piglets obtained from somatic cell cloning and the surrogate recipient females to confirm the identity of the donor cells used for nuclear transfer. DNA was extracted from an ear punch or tail clipping obtained from each newborn piglet and the recipients, as well as from the donor cells. Thirteen porcine DNA microsatellite markers (S0005, S00090, S0026, S0155, S0225, SW122, SW24, SW632, SW72, SW787, SW857, SW936, and SW951) were applied to confirm the genetic identity of the cloned piglets to that of the donor cells used for nuclear transfer.

\section{Polymerase chain reaction conditions}

A total of $12.5 \mathrm{ng}$ of porcine DNA, 5 pmol of each primer, and $0.1 \mathrm{U}$ of Tag polymerase were included in an $8 \mu \mathrm{L}$ reaction containing $1 \times$ Taq buffer; $1.5 \mathrm{mM} \mathrm{MgCl} ; 30 \mu \mathrm{M}$ each of dTTP, dGTP, and dCTP; $15 \mu \mathrm{M}$ dATP, and $0.1 \mu \mathrm{Ci}$ of $\left[\alpha^{-32} \mathrm{P}\right] \mathrm{dATP}$. The thermocycler profile was set for $1 \mathrm{~min}$ at $92^{\circ} \mathrm{C}, 28$ cycles of $30 \mathrm{~s}$ at $94^{\circ} \mathrm{C}, 1 \mathrm{~min}$ at the annealing temperature, $1 \mathrm{~min}$ at $72^{\circ} \mathrm{C}$, and a 5 -min final extension at $72^{\circ} \mathrm{C}$.

\section{Experimental design}

In Experiment 1, different sexes of donor cells (female or male fetal fibroblast cells) at 4 to 10 passages were transferred to in vitro-matured enucleated oocytes and in vitro and in vivo developmental competence and cell number of reconstructed embryos were examined. In Experiment 2, cloned embryos derived from female or male fetal fibroblasts were surgically transferred to surrogate mothers. When cloned piglets were delivered, we monitored the total duration of the pregnancy, birth weight, and placental weight of the offspring. We performed clinical and pathological examination after delivery and conducted a postmortem analysis of dead piglets. We subjected only recipient pigs and neonatal piglets to neonatal analysis and pathological findings.

\section{Statistical analysis}

Differences were analyzed among experiments using one-way analysis of variance after arc-sine transformation of the proportional data. Differences were considered significant at $\mathrm{p}<0.05$.

\section{RESULTS}

\section{Experiment 1: Nuclear transfer and development of reconstructed oocytes}

The effects of the donor cells on the ability of reconstructed embryos to develop to the blastocyst stage after seven days of in vivo or in vitro culture were evaluated. The blastocyst formation rate of in vitro (11.9\% for females vs $11.3 \%$ for males) and in vivo ( $7.2 \%$ for females vs $10.6 \%$ for males) conditions was not significantly different $(\mathrm{p}>0.05)$ between the sexes (Table 1). The mean cell number of in vitro blastocysts $(31.4 \pm 8.3$ for females vs $33.4 \pm 11.1$ for males) was not significantly different ( $p>0.05)$ between the sexes. In the two different fetal fibroblast groups, in vivo developmental ability was not significantly different, but the mean cell number of in vivo blastocysts (143.8 \pm 10.5 in females vs $159.2 \pm 14.8$ in males) was higher than the in vitro culture of SCNT groups $(31.4 \pm 8.3$ in females vs $33.4 \pm 11.1$ in males). Although the proportions of the reconstructed embryos that developed into in vivo blastocysts were not significantly different between groups using different donor cells, the cell number of in vivo blastocysts was higher than those of in vitro blastocysts (Table 1). In Figure 2, in vivo cultured SCNT blastocysts (A and B) display a higher cell number and more homogeneous cell morphology than in vitro cultured SCNT

Table 1. In vitro and in vivo development of cloned embryos derived from female and male fetal fibroblast donor cells

\begin{tabular}{|c|c|c|c|c|c|}
\hline \multicolumn{2}{|l|}{ Conditions } & \multirow{2}{*}{$\begin{array}{l}\text { Number of } \\
\text { fused }\end{array}$} & \multirow{2}{*}{$\begin{array}{l}\text { Number of oocytes } \\
\text { cleaved }(\%)\end{array}$} & \multirow{2}{*}{$\begin{array}{c}\text { Number of embryos developed } \\
\text { to blastocysts }(\%)\end{array}$} & \multirow{2}{*}{$\begin{array}{c}\text { Cell number of blastocysts } \\
\text { (range) }\end{array}$} \\
\hline Culture conditions & Sex of donor cells ${ }^{1)}$ & & & & \\
\hline \multirow[t]{2}{*}{ In vitro } & Female & 211 & $149(70.6)$ & $25(11.9)$ & $\begin{aligned} & 31.4 \pm 8.3 \\
&(17-45)\end{aligned}$ \\
\hline & Male & 231 & $158(68.4)$ & $26(11.3)$ & $\begin{array}{r}33.4 \pm 11.1 \\
(19-48)\end{array}$ \\
\hline \multirow[t]{2}{*}{ In vivo } & Female & $167^{3)}$ & - & $12(7.2)$ & $\begin{aligned} & 143.8 \pm 10.5 \\
&(130-158)\end{aligned}$ \\
\hline & Male & $180^{3)}$ & - & $19(10.6)$ & $\begin{aligned} & 159.2 \pm 14.8 \\
&(147-184)\end{aligned}$ \\
\hline
\end{tabular}

\footnotetext{
${ }^{1)}$ A total of 4 to 10 passaged porcine fetal fibroblasts. ${ }^{2)}$ Mean \pm standard deviation. ${ }^{3)}$ Number of embryos transferred into recipient.
} 


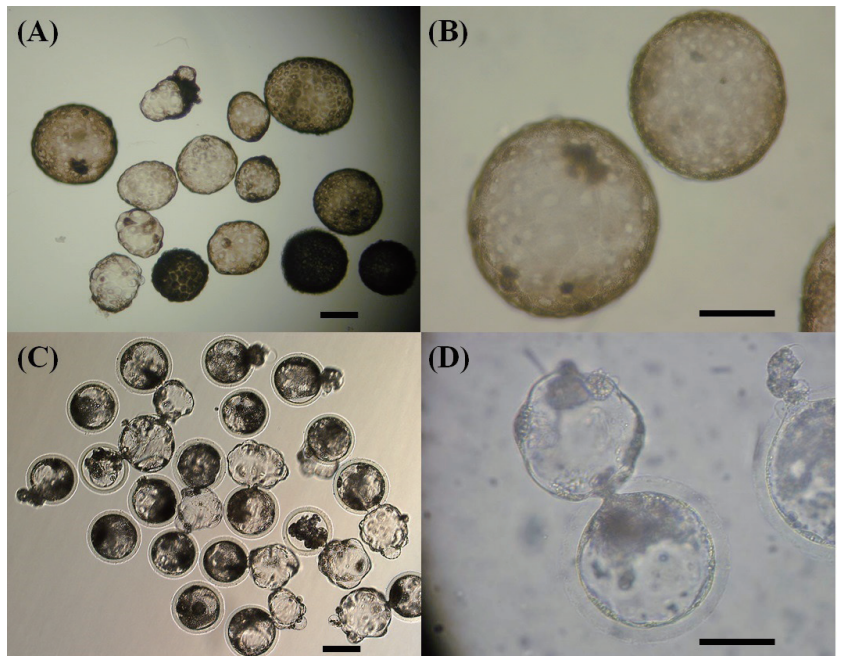

Figure 2. Representative SCNT blastocysts derived from in vivo cultured (A and B) and in vitro cultured (C and D) SCNT embryos. Scale bar: A and C $100 \mu \mathrm{m} ; \mathrm{B}$ and D $200 \mu \mathrm{m}$.

blastocysts (C and D).

\section{Experiment 2: Surgical embryo transfer and production} of cloned piglets

As shown in Table 2, five out of the seven pregnant surrogate gilts that received female reconstructed embryos were allowed to deliver naturally and farrowed on days 115 to 121 of gestation. The birth weight of the 15 female piglets ranged from 0.48 to $1.83 \mathrm{~kg}$. From the remaining two pregnant surrogate gilts that received reconstructed embryos with female donor cells, one pregnant recipient aborted two fetuses on day 46 of gestation and the other aborted during gestation, but the fetuses were inadvertently not recovered. Four of the seven pregnant gilts that received reconstructed embryos with male fibroblast cells produced eighteen male piglets on days 116 to 121 of gestation via vaginal delivery. One pregnant recipient delivered four live male piglets by cesarean section (Table 2), while two pregnant surrogate gilts aborted during gestation, but the fetuses were not recovered. The birth weights of male piglets ranged from 0.45 to $1.50 \mathrm{~kg}$. The average birth weight of the cloned piglets was not significantly different between the sexes $(1.36 \pm 0.29 \mathrm{~kg}$ in female piglets and $1.22 \mathrm{~kg} \pm 0.36$ in male piglets). The days of gestation length of cloned female and male piglets did not have a significant difference between the sexes (Table 2).

Next, we compared the efficacy of cloning piglets using the female and male fetal fibroblasts as donor cells. The survival rate in the female group (53.3\%, 8 out of 15 piglets) was higher than that in the male group (45.5\%, 10 out of 22 piglets), but these difference were not statistically significant (Table 3 ). Characteristics of the cloned piglets are summarized in Table 3. A total of 11 out of 37 cloned piglets (29.7\%) died within two weeks following birth. From the 12 cloned female piglets, 1 female piglet died during the first breast-feeding on day 1 , and 2 piglets died at days 11 and 14 from first breast-feeding failure of the surrogate. One piglet died from being crushed by the surrogate. A total of 7 out of the 17 cloned male piglets died within a week following birth. Among them, five piglets died between days 1 and 5 from failure to feed, which was related to the cesarean section birth of the surrogate, and two piglets died from diarrhea and crushing by two surrogates, respectively. The total remaining live cloned piglets were 8 female and 10 male, with the survival rate of cloned female and male piglets similar (53.3\% and $45.5 \%$, respectively).

Microsatellite analysis using 1 to 13 markers suggested that all 37 piglets were derived from the male or female fetal fibroblast cell line. Parentage analysis was performed on DNA obtained from ear punches of the SCNT piglets and the surrogate recipients

Table 2. Production of cloned piglets derived from nuclear transfer embryos

\begin{tabular}{|c|c|c|c|c|c|c|c|}
\hline \multirow{2}{*}{$\begin{array}{l}\text { Sex of } \\
\quad \text { donor cells }{ }^{1)}\end{array}$} & \multirow{2}{*}{$\begin{array}{l}\text { Number of embryos } \\
\text { transferred (range) }\end{array}$} & \multicolumn{3}{|c|}{ Number of surrogate recipients } & \multirow{2}{*}{$\begin{array}{l}\text { Total number of } \\
\text { cloned piglets born } \\
(\%)\end{array}$} & \multirow{2}{*}{$\begin{array}{c}\text { Average birth weight } \\
\text { of live birth piglets } \\
\text { (range) }\end{array}$} & \multirow{2}{*}{$\begin{array}{c}\text { Days of gestation } \\
\text { length } \\
\text { (range) }\end{array}$} \\
\hline & & Used & Pregnant $^{2)}(\%)$ & Farrowed (\%) & & & \\
\hline Female & $\begin{array}{c}6,789 \\
(64-400)\end{array}$ & 41 & $7(17.1)$ & $5(12.2)$ & $15(0.22)$ & $\begin{array}{l}1.36 \pm 0.29^{\mathrm{a}} \\
(0.48-1.83)\end{array}$ & $\begin{array}{r}118.4 \pm 2.4^{b} \\
(115-121)\end{array}$ \\
\hline Male & $\begin{array}{c}4,746 \\
(100-292)\end{array}$ & 25 & $7(28.0)$ & $5(20.0)$ & $22(0.46)$ & $\begin{array}{l}1.22 \pm 0.36^{\mathrm{a}} \\
(0.45-1.50)\end{array}$ & $\begin{array}{r}118.0 \pm 2.3^{b} \\
(116-121)\end{array}$ \\
\hline
\end{tabular}

\footnotetext{
1) Donor cell line: female, \#10 and \#1-1; male, \#5 and \#6 fetal fibroblast cell.

2) Female-recipient: two recipients aborted, Male-recipient: two recipients aborted.

${ }^{3)} \mathrm{A}$ piglet/embryos transferred eggs: female, 452.6; male, 215.7.

${ }^{a, b}$ Values with different superscripts differ significantly $(p<0.05)$.
}

Table 3. Neonatal post-birth characteristics and survival of cloned piglets produced from female or male fetal fibroblast donor cells

\begin{tabular}{|c|c|c|c|c|c|}
\hline \multirow{2}{*}{ Sex of donor cells } & \multirow{2}{*}{$\begin{array}{l}\text { Number of cloned } \\
\text { piglets born }\end{array}$} & \multicolumn{3}{|c|}{ Neonatal conditions } & \multirow{2}{*}{$\begin{array}{c}\text { No. of piglets surviving } \\
>0 \text { days }(\%)\end{array}$} \\
\hline & & Normal (\%) & Abnormal (\%) & Stillbirths (\%) & \\
\hline Female & 15 & $12(80.0)$ & $2(13.3)$ & $1(6.7)$ & $8(53.3)$ \\
\hline Male & 22 & $17(77.3)$ & $3(13.6)$ & $2(9.1)$ & $10(45.5)$ \\
\hline
\end{tabular}


to confirm that the piglets were identical to the donor cell line used. Results of the microsatellite marker analysis verified that the donor cell lines were the source of the genetic material used to produce the newborn piglets (Tables 4 and 5).

\section{DISCUSSION}

The donor somatic cell karyoplast is one of the important factors affecting the efficiency of somatic cell animal cloning. However, low cloning efficiency has hampered the production of cloned animals. Several studies have compared the effects of different types of donor cells to promote embryo development after SCNT in different species. In mice, an appropriate interaction between cell type and genotype can improve cloning efficiency [22]. In bovines, utilizing cumulus and ear fibroblast cells as donor cells was discovered to have better developmental competence of cloned embryos to the blastocyst stage than embryos reconstructed with uterine or oviductal cells [23]. Cloning with aborted calf-derived donor cells had a higher number of abnormalities than those derived from newborn or fetal cells [18]. Cumulus cells are a more efficient nuclear donor for SCNT than skin fibroblast and granulosa cell lines in buffalos [24]. The type of donor somatic cell is important for the development of cloned embryos; the fetal fibroblasts as a donor cell might be one of the best choices for positive SCNT in pigs [25]. However, comparisons from previous studies reveal that adult cells of any variety are inferior to fetal fibroblasts in terms of reconstructed embryo development. Fetal fibroblasts are highly undifferentiated cells unlike other cells retrieved from adult tissue. The superiority of fetal fibroblasts as shown in several studies might suggest that undifferentiated cells are more amenable to reprogramming after reconstruction than differentiated cells $[26,27]$. Although a female and male piglet have been produced previously [8], the efficacy of female or male somatic cells as donor nuclei for production of cloned animals has not been well documented. In a previous study, the production efficiencies of cloned miniature pigs using male and female fetal fibroblasts as nuclei donors ranged from $0.64 \%(2 / 314)$ to $0.9 \%(3 / 331)$ via the transfer of reconstructed embryos that had been cultured for 1 to 2 days into miniature and common domestic pigs [20]. In the present study, we investigated the effect of donor cell sex on the efficiency of pig cloning. Our results reveal that 5 recipients

Table 4. Microsatellite analysis of cloned female piglets derived from porcine fetal fibroblast cells ${ }^{1)}$

\begin{tabular}{|c|c|c|c|c|c|c|c|c|c|c|c|c|c|c|c|c|c|c|c|c|c|}
\hline \multirow{2}{*}{ Marker } & \multicolumn{5}{|c|}{ Genotype of recipient } & \multirow{2}{*}{$\begin{array}{c}\text { Donor } \\
\text { cell }\end{array}$} & \multicolumn{15}{|c|}{ Genotype of litters (female) } \\
\hline & RA & RB & RC & RD & RE & & $\mathrm{A} 1$ & $\mathrm{~A} 2$ & A3 & B1 & B2 & C1 & C2 & C3 & C4 & C5 & D1 & D2 & D3 & E1 & E2 \\
\hline PIG_X & 218 & 218 & 218 & 218 & 218 & 218 & 218 & 218 & 218 & 218 & 218 & 218 & 218 & 218 & 218 & 218 & 218 & 218 & 218 & 218 & 218 \\
\hline \multirow[t]{2}{*}{ S0005 } & 246 & 248 & 246 & 236 & 222 & 238 & 238 & 238 & 238 & 238 & 238 & 238 & 238 & 238 & 238 & 238 & 238 & 238 & 238 & 238 & 238 \\
\hline & 252 & 250 & 250 & 250 & 242 & 244 & 244 & 244 & 244 & 244 & 244 & 244 & 244 & 244 & 244 & 246 & 244 & 244 & 244 & 244 & 244 \\
\hline S00090 & 246 & 250 & 250 & 244 & 250 & 246 & 246 & 246 & 246 & 246 & 246 & 246 & 246 & 246 & 246 & 246 & 246 & 246 & 246 & 246 & 246 \\
\hline S0026 & 106 & 106 & 104 & 106 & 106 & 106 & 106 & 106 & 106 & 106 & 106 & 106 & 106 & 106 & 106 & 106 & 106 & 106 & 106 & 106 & 106 \\
\hline \multirow[t]{2}{*}{ S0155 } & 159 & 159 & 163 & 165 & 165 & 163 & 163 & 163 & 163 & 163 & 163 & 163 & 163 & 163 & 163 & 163 & 163 & 163 & 163 & 163 & 163 \\
\hline & 163 & 165 & 167 & 167 & 165 & 165 & 165 & 165 & 165 & 165 & 165 & 165 & 165 & 165 & 165 & 165 & 165 & 165 & 165 & 165 & 165 \\
\hline \multirow[t]{2}{*}{ S0225 } & 174 & 174 & 192 & 184 & 174 & & 192 & 192 & 192 & 192 & & & & & & & & 192 & 192 & 192 & 192 \\
\hline & 192 & 192 & 192 & 192 & 192 & 192 & 192 & 192 & 192 & 192 & 192 & 192 & 192 & 192 & 192 & 192 & 192 & 192 & 192 & 192 & 192 \\
\hline \multirow[t]{2}{*}{ SW632 } & 166 & 168 & 170 & 176 & 168 & 168 & 168 & 168 & 168 & 168 & 168 & 168 & 168 & 168 & 168 & 168 & 168 & 168 & 168 & 168 & 168 \\
\hline & 176 & 176 & 176 & 178 & 170 & 180 & 180 & 180 & 180 & 180 & 180 & 180 & 180 & 180 & 180 & 180 & 180 & 180 & 180 & 180 & 180 \\
\hline \multirow[t]{2}{*}{ SW72 } & 113 & 115 & 105 & 115 & 115 & 105 & 105 & 105 & 105 & 105 & 105 & 105 & 105 & 105 & 105 & 105 & 105 & 105 & 105 & 105 & 105 \\
\hline & 121 & 117 & 115 & 115 & 121 & 105 & 105 & 105 & 105 & 105 & 105 & 105 & 105 & 105 & 105 & 105 & 105 & 105 & 105 & 105 & 105 \\
\hline \multirow[t]{2}{*}{ SW787 } & 158 & 158 & 160 & 158 & 160 & 156 & 156 & 156 & 156 & 156 & 156 & 156 & 156 & 156 & 156 & 156 & 156 & 156 & 156 & 156 & 156 \\
\hline & 158 & 160 & 164 & 160 & 166 & 164 & 164 & 164 & 164 & 164 & 164 & 164 & 164 & 164 & 164 & 164 & 164 & 164 & 164 & 164 & 164 \\
\hline \multirow[t]{2}{*}{ SW857 } & 151 & 147 & 157 & 157 & 157 & 151 & 151 & 151 & 151 & 151 & 151 & 151 & 151 & 151 & 151 & 151 & 151 & 151 & 151 & 151 & 151 \\
\hline & 155 & 161 & 161 & 157 & 161 & 155 & 155 & 155 & 155 & 155 & 155 & 155 & 155 & 155 & 155 & 155 & 155 & 155 & 155 & 155 & 155 \\
\hline \multirow[t]{2}{*}{ SW936 } & 102 & 114 & 114 & 102 & 102 & 100 & 100 & 100 & 100 & 100 & 100 & 100 & 100 & 100 & 100 & 100 & 100 & 100 & 100 & 100 & 100 \\
\hline & 114 & 116 & 116 & 116 & 108 & 102 & 102 & 102 & 102 & 102 & 102 & 102 & 102 & 102 & 102 & 102 & 102 & 102 & 102 & 102 & 102 \\
\hline SW951 & 129 & 127 & 129 & 127 & 127 & 127 & 127 & 127 & 127 & 127 & 127 & 127 & 127 & 127 & 127 & 127 & 127 & 127 & 127 & 127 & 127 \\
\hline
\end{tabular}

1) Litter A1, 2, and 3 came from recipient RA; Litter B1 and 2 came from recipient RB; Litter C1, 2, 3, 4, and 5 came from recipient RC; Litter D1, 2, and 3 came from recipient RD; and Litter $\mathrm{E} 1$ and 2 came from recipient RE. 
Table 5. Microsatellite analysis of cloned male piglets derived from porcine fetal fibroblast cells"

\begin{tabular}{|c|c|c|c|c|c|c|c|c|c|c|c|c|c|c|c|c|c|c|c|c|c|c|c|c|c|c|c|}
\hline \multirow{2}{*}{ Marker } & \multicolumn{5}{|c|}{ Genotype of recipient } & \multirow{2}{*}{$\begin{array}{c}\text { Donor } \\
\text { cell }\end{array}$} & \multicolumn{21}{|c|}{ Genotype of litters (male) } \\
\hline & $\mathrm{RF}$ & RG & RH & RI & RJ & & F1 & F2 & F3 & F4 & F5 & G1 & G2 & H1 & H2 & H3 & 11 & 12 & 13 & 14 & 15 & 16 & J1 & $\mathrm{J} 2$ & J3 & J4 & J5 \\
\hline \multirow[t]{2}{*}{ IIG_X } & 218 & & 218 & & 218 & 218 & 218 & 8 & 218 & 18 & 218 & 18 & 218 & 18 & 218 & 218 & 218 & 218 & 218 & 218 & 218 & 218 & 218 & 218 & 18 & 218 & 218 \\
\hline & 218 & & 8 & & & & & & & & & & & & & & & & & & & & & 18 & & 18 & 218 \\
\hline \multirow[t]{2}{*}{ IG_Y } & - & - & - & - & - & & 226 & 226 & 226 & 226 & 226 & 226 & 226 & & 226 & 226 & 226 & 226 & 226 & 226 & 226 & 226 & 226 & 226 & 226 & 226 & \\
\hline & - & - & - & & - & & 226 & 226 & 226 & 226 & 226 & 226 & 226 & 226 & 226 & 226 & 226 & 226 & 226 & 226 & 226 & 226 & 226 & 226 & 226 & 226 & 226 \\
\hline \multirow[t]{2}{*}{50005} & 222 & 210 & 242 & 238 & 230 & & 234 & 234 & 234 & 234 & 34 & 234 & 234 & 234 & 234 & 234 & 234 & 234 & 234 & 234 & 234 & 234 & 234 & 234 & 234 & 34 & 234 \\
\hline & 242 & 236 & 246 & & & & 238 & 238 & & 238 & & 238 & 238 & & 238 & & 238 & & & 238 & & 38 & & 38 & & & \\
\hline \multirow[t]{2}{*}{500090} & 250 & 248 & 246 & 50 & 250 & & 246 & 246 & 246 & 246 & & 246 & 246 & 46 & 246 & & 246 & & & 246 & & & & 6 & & & \\
\hline & 250 & 250 & 250 & 52 & 252 & & 248 & 248 & 248 & 248 & & 248 & 248 & 18 & 248 & & 2 & & & 248 & & & & & & & \\
\hline \multirow[t]{2}{*}{ S0026 } & 100 & 02 & 100 & 00 & 10 & & 102 & 102 & 102 & 102 & & 102 & 102 & 102 & 102 & 10 & 10 & 102 & 2 & 102 & 02 & & & & & & 02 \\
\hline & 106 & 04 & 104 & 84 & & & 106 & 106 & & 106 & & 106 & & & & & & & & 106 & & & & & & & \\
\hline \multirow[t]{2}{*}{00155} & 165 & 65 & 165 & & 16 & & & 163 & & 16 & & 163 & & & & & & & & 163 & & & & & & & 63 \\
\hline & 165 & 167 & 167 & 165 & & & 165 & 165 & & & & & & & & & & & & 165 & & & & & & & \\
\hline \multirow[t]{2}{*}{ S0225 } & 174 & 17 & 174 & 1 & 18 & & 19 & 19 & & & & & & & & & & & & & & & & & & & \\
\hline & 19 & & & & & & & & & & & & & & & & & & & & & & & & & & \\
\hline \multirow[t]{2}{*}{ SW122 } & 11 & & & & & & & & & & & & & & & & & & & & & & & & & & \\
\hline & 130 & 122 & & & & & & & & & & & & & & & & & & & & & & & & & \\
\hline \multirow[t]{2}{*}{ sW24 } & 112 & 12 & 104 & & 10 & & 11 & & & & & & & & & & & & & 118 & & & & & & 18 & 11 \\
\hline & 12 & & 10 & & & & & & & & & & & & & & & & & & & & & & & & \\
\hline \multirow[t]{2}{*}{ W632 } & 168 & & & & & & $1 \varepsilon$ & & & & & & & & & & & & & 1 & & & & & & & \\
\hline & 17 & 1 & & & & & 18 & $1 \varepsilon$ & 18 & & & & & & & 18 & & & & 180 & & & 100 & 30 & & 30 & 80 \\
\hline \multirow[t]{2}{*}{ W72 } & 115 & 105 & 105 & & 105 & & 11 & 11 & 11 & 11 & 1 & & 1 & & 11 & 11 & & 1 & & 113 & & & & 13 & 13 & 13 & 113 \\
\hline & 121 & & & & & & 115 & & & 11 & & & & & & & & & & 115 & & & & 15 & 15 & 15 & 115 \\
\hline \multirow[t]{2}{*}{ SW787 } & 160 & 156 & 158 & 158 & 158 & & 156 & 156 & 156 & 156 & 156 & 156 & 156 & 156 & 156 & 156 & 156 & 156 & 156 & 156 & 156 & 156 & 156 & 56 & 156 & 56 & 156 \\
\hline & 166 & 160 & 160 & 158 & 166 & & 158 & 158 & 158 & 158 & 158 & 158 & 158 & 158 & 158 & 158 & 158 & 158 & 158 & 158 & 158 & 158 & 158 & 158 & 158 & 58 & 158 \\
\hline \multirow[t]{2}{*}{ SW857 } & 157 & 147 & 147 & 157 & & & & 151 & & & & & & & & & & & & 151 & 1 & 1 & 51 & 51 & 51 & 51 & 151 \\
\hline & 161 & 161 & & & & & & 15 & & & & & & & & & & & & & & & 55 & 65 & 55 & 5 & 55 \\
\hline \multirow[t]{2}{*}{ sW936 } & 102 & 102 & 108 & 10 & & & & 10 & & 10 & & & & & 10 & 102 & & 10 & & 102 & & & 02 & 2 & 02 & 02 & 02 \\
\hline & 108 & 108 & 116 & $10 \varepsilon$ & & & & & & & & & & & & & & & & 114 & & & 14 & 14 & 14 & 14 & 14 \\
\hline \multirow[t]{2}{*}{ SW951 } & 127 & 127 & 127 & 12 & 127 & & 121 & 12 & & 12 & & & & & & & & & & 127 & & & & & & 127 & 127 \\
\hline & 127 & 129 & 127 & & 129 & & 135 & & 135 & & 135 & & 135 & & 135 & 135 & 135 & 135 & 135 & 135 & 135 & 135 & 135 & 135 & 135 & 135 & 135 \\
\hline
\end{tabular}

1) Litter F1, 2, 3, 4, and 5 came from recipient RF; Litter G1 and 2 came from recipient RG; Litter H1, 2, and 3 came from recipient RH; Litter I1, 2, 3, 4, 5, and 6 came from recipient Rl; and Litter J1, 2, 3, 4, and 5 came from recipient RJ.

delivered 15 female piglets and the other 5 recipients delivered 22 male piglets after the transfer of 11,535 female and male reconstructed embryos into 66 recipients. A total of 18 (8 female and 10 male) piglets survived for greater than 60 days. Although there were no significant differences in pregnancy and delivery rates between the groups, the production rates of cloned piglets derived from the reconstruction of male fibroblast cells were higher than the reconstruction of female fibroblast cells. Considering data from previous studies, the pregnancy rate obtained in the present study (female $17.1 \%$ and male $28.0 \%$ ) after the transfer of eggs matured in vitro was similar to that in studies using in vivo-matured eggs and serial nuclear transfer (29\%; [4]) and in vitro-matured oocytes receiving fetal somatic cells (23\%; [2]).

In recent years, several studies have reported that the pregnancy rates of SCNT pigs using fetal fibroblasts as nuclei donors ranged from $43 \%$ to $100 \%$ via transferring of reconstructed embryos cultured for 1 to 2 days into recipients [15,16,20,28]. These studies also discovered that the cell number of female and male in vivo blastocysts was higher than those of in vitro blastocysts, while the average birth weight of the cloned piglets and the day of gestation length of cloned female and male were not significantly different between female and male piglets. In the present study, the survival rates and birth weights of female cloned piglets were higher than those of cloned male piglets. Although the numbers of recipients in other studies were limited, the cloned embryo pregnancies in the present study were lower than those for the pig somatic cell cloning studies with in vivomatured oocytes [8] and in vitro-matured oocytes [9,29].

Previous studies have reported that SCNT-derived clones are prone to various abnormal phenotypes, including large birth weights [30,31]. Morphological abnormalities of somatic cell cloning have been observed in cloned male piglets [32]. Postnatal death of young and abnormality of male somatic cell cloning was higher than those of female somatic cell cloning in bovines [33]. It has also been reported that a cloned male piglet died from suffocation because of regurgitated ingesta within the respiratory cavities on the day following birth [8]. Some studies have reported that all cloned male piglets appeared quite healthy [2], while other studies have observed a few abnormal phenotypic problems $[9,29]$. In the present study, the cloned piglets might have a number of physiological defects such as failure of first feeding. Among the cloned piglets that died within two weeks following delivery, male piglets had a higher number (7/17, 41.2\%) than did female clones (4/12, 33.3\%). Considering data obtained from other studies, the competence of SCNT 
might be due to the differences of donor cell lines. In particular, the phenotypic abnormality of cloned pigs may be induced by damage during in vitro culture of donor cells. However, whether donor cell types cause multiple-organ failure and sudden early death in cloned males needs to be investigated further. Although we have no explanation for the difference in the cause of death observed between the sexes, further studies are necessary to increase the successful development to term and the survival rate of cloned piglets. In conclusion, the present study indicates that the type of donor cell lines is one of the critical factors for improving the efficiency of SCNT in pigs, while the sex difference might not affect the efficiency of SCNT in pigs.

\section{CONFLICT OF INTEREST}

We certify that there is no conflict of interest with any financial organization regarding the material discussed in the manuscript.

\section{ACKNOWLEDGMENTS}

This work was supported by Korea Institute of Planning and Evaluation for Technology in Food, Agriculture, Forestry and Fisheries (IPET), 111047-5, http://www.ipet.re.kr/.

\section{REFERENCES}

1. Wilmut I, Schnieke AE, McWhir J, Kind AJ, Campbell KHS. Viable offspring derived from fetal and adult mammalian cells. Nature 1997; 385:810-3.

2. Betthauser J, Forsberg E, Augenstein M, et al. Production of cloned pigs from in vitro systems. Nat Biotechnol 2000;18:1055-9.

3. Onishi A, Iwamoto M, Akita T, et al. Pig cloning by microinjection of fetal fibroblast nuclei. Science 2000;289:1188-90.

4. Polejaeva IA, Chen SH, Vaught TD, et al. Cloned pigs produced by nuclear transfer from adult somatic cells. Nature 2000;407:86-90.

5. Prather RS, Shen M, Dai Y. Genetically modified pigs for medicine and agriculture. Biotechnol Genet Eng Rev 2008;25:245-65.

6. Schmidt M, Kragh PM, Li J, et al. Pregnancies and piglets from large white sow recipients after two transfer methods of cloned and transgenic embryos of different pig breeds. Theriogenology 2010; 74:1233-40.

7. Vajta G, Callesen H. Establishment of an efficient somatic cell nuclear transfer system for production of transgenic pigs. Theriogenology 2012;77:1263-74.

8. Boquest AC, Grupen CG, Harrison SJ, et al. Production of cloned pigs from cultured fetal fibroblast cells. Biol Reprod 2002;66:1283-7.

9. Walker SC, Shin T, Zaunbrecher GM, et al. A highly efficient method for porcine cloning by nuclear transfer using in vitro-matured oocytes. Cloning Stem Cells 2004;4:105-12.

10. Koo OJ, Park HJ, Kwon DK, et al. Effect of recipient breed on delivery rate of cloned miniature pig. Zygote 2009;17:203-7.

11. Petersen B, Lucas-Hahn A, Oropeza M, et al. Development and validation of a highly efficient protocol of porcine somatic cloning using preovulatory embryo transfer in peripubertal gilts. Cloning Stem Cells 2008;10:355-62.

12. Huang Y, Ouyang H, Yu H, et al. Efficiency of porcine somatic cell nuclear transfer - a retrospective study of factors related to embryo recipient and embryos transferred. Biol Open 2013;2:1223-8.

13. Rim CH, Fu Z, Bao L, et al. The effect of the number of transferred embryos, the interval between nuclear transfer and embryo transfer, and the transfer pattern on pig cloning efficiency. Anim Reprod Sci 2013;143:91-6.

14. Liu Y, Li J, Lovendahl P, et al. In vitro manipulation techniques of porcine embryos: a meta-analysis related to transfers, pregnancies and piglets. Reprod Fertil Dev 2014;27:429-39.

15. Li Z, Shi J, Liu D, et al. Effects of donor fibroblast cell type and transferred cloned embryo number on the efficiency of pig cloning. Cell Reprogram 2013;15:35-42.

16. Shi J, Zhou R, Luo L, et al. Influence of embryo handling and transfer method on pig cloning efficiency. Anim Reprod Sci 2015;154:121-7.

17. Wei H, Qing Y, Pan W, et al. Comparison of the efficiency of Banna miniature inbred pig somatic cell nuclear transfer among different donor cells. PLoS ONE 2013;8:e57728.

18. Kato Y, Tani T, Tsunoda Y. Cloning of calves from various somatic cell types of male and female adult, newborn and fetal cows. J Reprod Fertil 2000;120:231-7.

19. Wakayama T, Yanagimachi R. Mouse cloning with nucleus donor cells of different age and type. Mol Reprod Dev 2001;58:376-83.

20. Kurome M, Ishikawa T, Tomii R, et al. Production of transgenic and non-transgenic clones in miniature pigs by somatic cell nuclear transfer. J Reprod Dev 2008;54:156-63.

21. Yin XJ, Cho SK, Park MR, et al. Nuclear remodelling and the developmental potential of nuclear transferred porcine oocytes under delayedactivated conditions. Zygote 2003;11:167-74.

22. Wakayama T, Perry ACF, Zuccotti M, Johnson KR, Yanagimachi R. Full-term development of mice from enucleated oocytes injected with cumulus cell nuclei. Nature 1998;394:369-74.

23. Cho JK, Lee BC, Park JI, et al. Development of bovine oocytes reconstructed with different donor somatic cells with or without serum starvation. Theriogenology 2002;57:1819-28.

24. Pandey A, Gupta SC, Gupta N. Comparative potential of cultured skin fibroblast, cumulus, and granulosa cell to produce somatic cell nuclear transfer (SCNT) preimplantation embryos in buffaloes (Bubalus bubalis) in relation to gene expressions. Cell Reprogram 2010;12:357-68.

25. Lee GS, Hyun SH, Kim HS, et al. Improvement of a porcine somatic cell nuclear transfer technique by optimizing donor cell and recipient oocyte preparations. Theriogenology 2003;59:1949-57.

26. Rideout WM III, Eggan K, Jaenisch R. Nuclear cloning and epigenetic reprogramming of the genome. Science 2001;293:1093-8.

27. Yamazaki Y, Makino H, Hamaguchi-Hamada K, et al. Assessment of the developmental totipotency of neural cells in the cerebral cortex of mouse embryo by nuclear transfer. Proc Natl Acad Sci USA 2001; 98:14022-6 
28. Huan Y, Hu K, Xie B, et al. Ovulation statuses of surrogate gilts are associated with the efficiency of excellent pig cloning. PLoS ONE 2015;10:e0142549.

29. Yin XJ, Tani T, Yonemura I, et al. Production of cloned pigs from adult somatic cells by chemically assisted removal of maternal chromosomes. Biol Reprod 2002;67:442-6.

30. Martin M, Adams C, Wiseman B. Pre-weaning performance and health of pigs born to cloned (fetal cell derived) swine versus noncloned swine. Theriogenology 2004;62:113-22.

31. Hirayama H, Sawai K, Hirayama M, et al. Prepartum maternal plasma glucose concentrations and placental glucose transporter mRNA expression in cows carrying somatic cell clone fetuses. J Reprod Dev 2011;57:57-61.

32. Hill JR, Burghardt RC, Jones K, et al. Evidence for placental abnormality as the major cause of mortality in first-trimester somatic cell cloned bovine fetuses. Biol Reprod 2000;63:1787-94.

33. Heyman Y, Chavatte-Palmer P, LeBourhis D, et al. Frequency and occurrence of late-gestation losses from cattle cloned embryos. Biol Reprod 2002;66:6-13. 